\title{
Tooth preparation design of dental laminate veneer: a review article
}

\author{
Eun-Hye Jo, Kyung-Ho Ko, Chan-Jin Park, Lee-Ra Cho, Yoon-Hyuk Huh* \\ Department of Prosthodontics and Research Institute of Oral Science, Gangneung-Wonju National University, Gangneung, \\ Republic of Korea
}

Tooth preparation design is essential for successful laminate veneer treatment. Preservative tooth preparation limited on enamel, supra-margin advantageous for plaque control, and maintaining contact points known as a standard concept. However, the tooth preparation design has been the controversial issue. In biomechanical considerations, the incisal coverage should be decided on esthetic needs and necessity for the anterior guidance reconstruction. In occasion for sufficient enamel thickness, preparation can prolong to the palatal side but not recommended at palatal concavity. Elongation to contact point is selective option according to the cases. If an old resin restoration located at contact area, laminate veneer should cover over half area of that after surface treatment. The laminate veneer can be also selected at a partially discolored tooth root canal therapy (RCT) and at this occasion, the fiber-reinforced composite (FRC) posts are recommended. (J Dent Rehabil Appl Sci 2016;32(3):149-57)

Key words: laminate; tooth preparation; enamel; palatal concavity; contact area

\section{서론}

접착치의학의 기술적 발전과 더불어 환자들의 최소한 의 치아형성에 대한 요구가 증가함에 따라 라미네이트는 심미치과보철학의 대표적인 술식 중의 하나가 되었다. 라 미네이트의 장기적인 성공률은 교합관계, 치아형성디자 인, 접착 등에 영향을 받으며, ${ }^{1}$ Burke ${ }^{2}$ 는 법랑질에 국한된 보존적인 치아형성이 가장 중요한 요소라고 보고하였다.

라미네이트를 위한 치아형성에 대한 개념은 시대에 따라 변화하였다. 초창기에는 심미를 위한 수복물이므 로 비침습적인 접근이 적절하다는 이유로 '무삭제 술식 (no preparation technique)'이 선호되었다. 그러나 과풍 융으로 인한 치주적인 문제점들이 발생하면서 최소 침습 적 접근법(minimally invasive approach)에 따른 치아형 성을 선호하게 되었다. 그 후 1990년대 열가압도재(heat-

\footnotetext{
*Correspondence to: Yoon-Hyuk Huh

Assistant Professor, Department of Prosthodontics, College of Dentistry, Gangneung-Wonju National University, 7 Jukheon-gil, Gangneung, 25457, Republic of Korea

Tel: + 82-33-640-2761, Fax: + 82-33-640-3103, E-mail: vino@gwnu.ac.kr Received: September 1, 2016/Last Revision: September 9, 2016/Accepted: September 12, 2016
}

pressed ceramic)가 개발된 초기에는 다소 두꺼운 두께가 필요하여 $1.0 \mathrm{~mm}$ 정도의 깊은 삭제를 시행하였으나 상 아질 노출에 따른 문제점들이 보고되면서 현재 최소 침 습적인 치아형성으로 개념이 재정립 되었다. ${ }^{3}$

치아형성방법으로는 $0.3-0.5 \mathrm{~mm}$ 의 법랑질 삭제와 치 은연선상의 chamfer 변연이 추천되나 절단면피개에 관하 여는 논쟁의 여지가 있다. ${ }^{4}$ 또한 라미네이트 성공률에 관 한 문헌에서 파절(fracture), 미세누출(microleakage), 탈 락(debonding)이 주된 합병증이며 교합양식, 접착실패와 더불어 치아형성디자인이 주요한 실패의 원인으로 지적 되고 있다. ${ }^{5-7}$

본 문헌고찰에서는 치아형성디자인의 정립된 부분과 논쟁 중인 의견에 대해 고찰해보고 임상적으로 호발하는 라미네이트의 실패양상을 치아형성디자인 측면에서 논 의해 보고자 한다.

Copyright@ 2016 The Korean Academy of Stomatognathic Function and Occlusion. (c) It is identical to Creative Commons Non-Commercial License. 


\section{문헌고찰}

\section{절단면형성}

라미네이트의 절단면피개에 관하여 상반된 연구결과 가 존재한다. 절단면피개가 더 좋은 성공률을 보인다는 보고와, ${ }^{8,9}$ 유의한 차이가 없다고 하는 보고가 있다. ${ }^{10}$ 절 단면피개 시 강도에 관해서도 상반된 연구결과가 있는데 Hui 등 ${ }^{11}$ 은 절단면을 피개하지 않은 경우 치아의 탄성이 높아서 동적 응력에 더 강하다고 한 반면 절단면을 피개 한 경우 라미네이트의 기계적 강도의 증가를 보인 여러 보고들이 존재한다. ${ }^{12-14}$ 절단면을 피개하지 않으면 라미 네이트의 가장 큰 장점인 최소 침습적인 치아형성이 가능 하다. 반면 절단면 피개의 장점으로는 접착과 유지력이 증가한다는 것과 수복물의 투명도가 향상되며 적합에 유 리하고 적절한 전방유도의 재형성이 가능하다는 것이다.

절단면피개의 디자인으로는 'butt joint형'과 '구개 chamfer형'이 있다(Fig. 1). 이 둘의 파절강도에 관하여도 상반된 연구결과가 존재한다. 구개 chamfer형은 움직임 이 적어서 기계적으로 안정적이며 접착면적이 넓고 법랑 소주의 절단방향이 접착에 유리하다. ${ }^{13}$ 또한 충격흡수역 할을 하는 시멘트층이 넓으므로 응력분산에 유리하다. ${ }^{14}$ 이에 반해 butt joint형은 응력이 적게 발생하는 위치에 변연이 설계된다는 장점이 있다.

이차원적 유한요소분석을 통해 라미네이트의 응력 분산을 연구한 Magne와 Douglas ${ }^{13}$ 는 구개오목(palatal
A

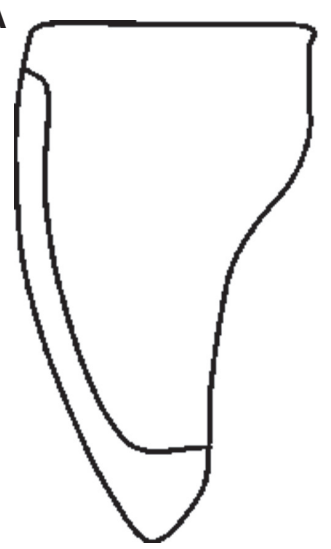

B

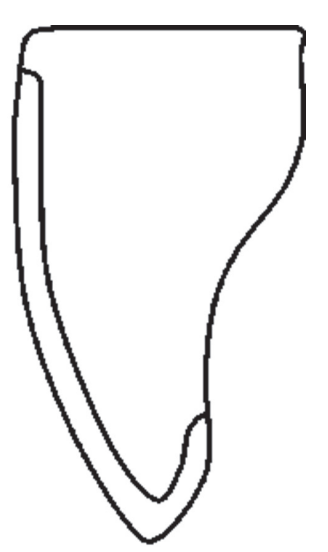

Fig. 1. Schematic diagram of specimen preparation. Butt joint type (A), Palatal chamfer type (B). concavity)에 변연이 위치하는 수복물에서 높은 응력이 발생하므로 변연을 구개오목에 근접하지 않도록 설계하 는 것을 추천하였다. 또한 Magne 등 $^{15}$ 은 균열이 발생한 라미네이트와 발생하지 않은 라미네이트를 관찰한 결과 도재와 시멘트 자체의 두께보다 균열의 발생에 영향을 주는 것은 도재와 시멘트의 비율이며, 도재/시멘트의 비 율이 낮은(3.0이하) 경우 균열의 발생이 증가한다고 보고 하였다. 따라서 충분하고 일정한 두께의 도재를 갖도록 치아를 형성하는 것이 중요하지만 구개측은 법랑질의 두 께가 얇아 이러한 치아형성이 어렵다.

구개 chamfer형은 변연이 구개오목에 근접하며 구개 측에서의 도재/시멘트의 비율이 낮아져 균열의 발생가 능성이 높아진다. 구개오목에 변연이 위치하는 경우는 흔하지 않은데, 인접면을 연장하는 경우에 발생할 수 있 고, 마모가 심해 짧은 치아에서 구개 chamfer형으로 디 자인할 경우 발생할 수 있다. 이때는 butt joint형으로 디 자인 하는 것이 추천된다. 또한 구개 chamfer형의 단점으 로는, 법랑질두께가 얇은 구개측에서 상아질의 노출 가 능성을 높이는 것이므로 법랑질의 두께가 충분할 때만 구개 chamfer형의 디자인이 추천된다. ${ }^{13}$ Butt joint형은 이외에도 치아형성과정 및 기공 과정이 더 단순하여 오차 가 적다는 장점이 있으며 적합 시 삽입로가 다양하여 치 아형성과정에서 언더컷을 남겨도 장착이 가능하다. ${ }^{16}$

Feathered edge형, butt joint형, 구개 chamfer형의 파 절강도에 관한 연구들을 살펴보면 ${ }^{13,14,17-23}$ 응력분산 측 면에서, 구개측에 하중을 가할 때 feathered edge형보 다 구개 chamfer형이 유리하다고 하였으나 ${ }^{16}$ butt joint 형을 포함하여 직접 비교한 실험은 없었다. 파절강도에 서 feathered edge형은 대부분 높게 나타났다. ${ }^{17-20}$ 구개 chamfer형과 butt joint형의 파절강도를 비슷한 실험조건 에서 직접적으로 비교한 2가지 연구는 서로 상반된 결과 를 보였다. ${ }^{17,22}$ 구개측에 수직으로 정적인 하중을 가하였 을 때 Castelnuovo 등 ${ }^{17}$ 은 butt joint형의 파절강도가 더 높다는 결과를 얻었고, Schmidt 등 22 은 구개 chamfer형의 파절강도가 더 높다고 하였다. 이러한 상반된 결과의 원 인은 두 실험에서 설정한 구개 chamfer형태가 서로 다르 기 때문으로 판단된다. Schmidt 등릐 듸자인에서는 구 개 chamfer형의 절단면 피개면적이 더 넓어 절단면에서 전단결합강도를 얻을 수 있었고, 구개측 연장 부분이 기 계적인 안정성을 제공하였을 것이다. 따라서 적절하게 설 계된 구개 chamfer형은 기계적으로도 더 유리하다고 생 각된다(Fig. 2). 
A
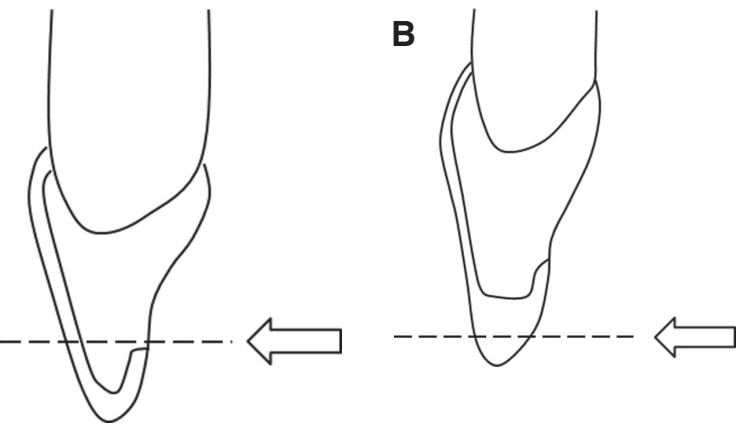

Fig. 2. (A) Specimen preparation design of Castelnuovo et al., ${ }^{17}$ (B) Specimen preparation design of Schmidt et al. $^{22}$

문헌고찰을 통해 라미네이트의 성공률을 조사한 Shetty 등 ${ }^{24}$ 에 따르면 절단면을 피개하는 것이 더 성공률 이 높았다. 그러나 feathered edge형은 치아를 더 보존적 으로 수복할 수 있다는 장점이 있으며 파절강도가 낮다 고 해도 생리적으로 전치가 받는 힘의 최고치(150 - 300 $\mathrm{N})$ 을 훨씬 능가하는 파절강도 $(527-598 \mathrm{~N})$ 를 보였다. ${ }^{19}$ 따라서 절단면의 형태나 길이 수정이 필요하지 않은 경우 에는 feathered edge형이 추천된다. 절단면의 수정이 필 요한 경우에는 법랑질의 두께가 충분하면 구개 chamfer 형이, 그렇지 않은 경우에는 butt joint형이 추천된다. 마 모된 치아에서는 butt joint형이 추천된다. 치아 마모량이 파절강도에 미치는 영향에 대하여는 논쟁의 여지가 있으 나 대부분의 연구에서 $2 \mathrm{~mm}$ 정도까지는 라미네이트의 파절강도가 높은 것으로 보고되었다. ${ }^{25,26}$ 즉, $2 \mathrm{~mm}$ 정도 의 파절 혹은 마모된 치아에서는 라미네이트 수복을 치 료옵션으로 고려할 수 있다.

\section{인접면형성}

인접면까지 연장하여 라미네이트를 형성하는 것은 변 연을 숨겨 심미성을 높이며 접착면적을 넓혀 유지력을 증 가시키는 장점이 있다. 라미네이트 인접면연장의 일반적 인 적응증으로는 위치 이상, 정중이개, 치간부 검은 삼각 (black triangle), 인접면수복물의 존재 등의 경우이며 착 색이 있거나 전장관(full veneer)과 인접한 치아의 라미네 이트 수복 시에도 심미성을 위해 접촉점을 넘어서는 치아 형성이 필요할 수 있다. ${ }^{27}$ 어느 정도 구개측으로 연장해 야 하는지에 관해 명확한 합의는 없지만 Rosential ${ }^{28}$ 은 1 $\mathrm{mm}$ 를 제안하였고, $\mathrm{Knight}^{29}$ 는 인접면 선각(line angle)까 지의 연장을 제안하였으며, 치간공간이 클수록 보다 구 개측으로 연장할 것을 추천하였다. ${ }^{27}$

Chun 등 ${ }^{30}$ 은 상악전치에서 순면 비니어(두께 $0.5 \mathrm{~mm}$ ), $3 / 4$ 비니어(두께 $0.5 \mathrm{~mm}$ ), 전부 전장관(두께 $1.0 \mathrm{~mm}$ )의 파절강도를 비교하였을 때 유의한 차이가 없다고 하였으 며 변연이 상아질에 위치하는 경우는 법랑질에 위치하는 경우보다 파절강도가 낮아진다고 하였다(Fig. 3). 3/4 비 니어와 전부 전장관은 치아삭제량에서 2 배 정도 차이가 나기 때문에 임상적으로 $3 / 4$ 비니어의 수복이 치질보존 측면에서 더 유리할 수 있다.

Guess와 Stappert ${ }^{31}$ 는 동일한 두께의 butt joint형의 라 미네이트와 전부 전장관 라미네이트 수복물의 5년간 성 공률을 비교한 결과, 전부 전장관 라미네이트의 높은 성 공률 $(100 \%)$ 과 생존율 $(85 \%)$ 을 보고하였고 이는 butt joint형 라미네이트의 성공률 $(97.6 \%)$ 과 생존율 $(72 \%)$ 보 다 높았다. 전통적인 라미네이트와 전부도재관의 중간 정도의 치아형성을 하는 전부 전장관 라미네이트는 수복 물의 변연이 설면결절에 위치하여 발생되는 응력이 적고 접착 면적이 넓다.
A

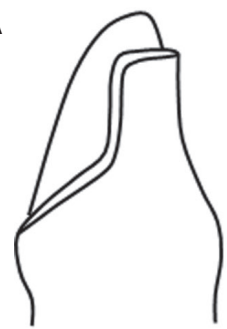

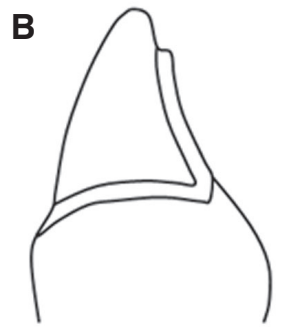

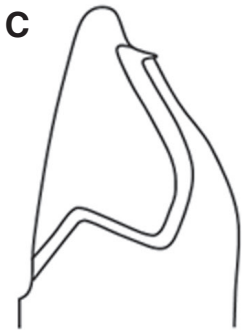

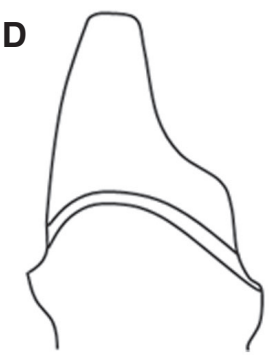

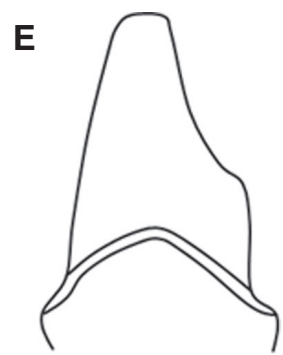

Fig. 3. Specimen preparation design of Chun et al. ${ }^{30}$ (A) labial veneer, (B) $3 / 4$ veneer, enamel, (C) $3 / 4$ veneer, dentin, (D) full veneer, enamel, (E) full veneer, dentin. 
인접면연장을 할 때 구개측으로의 연장 정도는 다양하 게 할 수 있는데 Magne와 Douglas ${ }^{13}$ 에 따르면 인접면을 연장하는 경우에 응력이 높은 구개오목에 변연이 위치하 지 않도록 하는 것이 필요하다. 따라서 구개측으로 약간 의 연장부를 가지는, Chun 등 ${ }^{30}$ 의 $3 / 4$ 비니어 디자인이나 설면결절에 변연이 위치하는 Guess와 Stappert ${ }^{31}$ 의 전부 전장관 디자인이 기계적으로 유리할 것이다.

\section{변연형성}

심미성과 치태 조절 용이성을 위하여 가능한 치은연선 상으로 형성하는 변연이 추천된다.

Troedson와 Dérand ${ }^{32}$ 는 라미네이트의 응력발생에서 치경부 변연디자인이 미치는 영향은 크지 않으며, 접착 의 상태가 가장 중요하고, 변연에서 접착이 불완전한 경 우에 중앙에서 접착이 불완전한 경우보다 큰 응력이 나 타난다고 하였다. Seymour 등 ${ }^{16}$ 은 knife-edge, chamfer, shoulder 변연을 비교 시 knife-edge 변연에서 가장 작은 응력이 발생함을 보고하였다. Shoulder 변연은 날카로운 내부 선각에 응력이 집중되어 가장 큰 응력이 나타났다.

Knife-edge 변연은 응력이 적으나 변연이 불명확하며 파절가능성이 존재한다. 하지만 명확한 chamfer 변연은 상아질의 노출을 증가시킬 수 있다. ${ }^{33}$ 따라서 knife-edge 와 chamfer의 중간 형태인 long chamfer 변연이 추천되 는데, long chamfer 변연은 와연우각(cavosurface angle) 을 둔각이 되도록 하여 법랑질 소주를 노출시켜 산 부식 을 용이하게 한다. ${ }^{34}$

\section{임상적 상황에서의 고려사항}

라미네이트의 성공률에 관한 문헌들에 따르면 실패유 형은 파절, 미세누출, 탈락 등이 주로 나타난다. ${ }^{5-7}$ 파절의 원인으로는 부적절한 치아형성, 과하중 등이 있다. 미세 누출은 상아질에 변연을 형성하는 경우에 증가하며 적절 한 접착을 시행하는 경우 감소할 수 있다. 지대치의 법랑 질이 부족할 경우에는 탈락이 증가하는데, 접착력이 감 소하며 치아와 도재 라미네이트의 강성도(stiffness) 차이 가 커지기 때문이다.

Burke $^{35}$ 는 라미네이트 성공률에 관한 문헌고찰에서 법 랑질에 국한된 치아형성이 가장 중요한 요소라고 하였다. $F^{F r i e d m a n}{ }^{36}$ 은 라미네이트가 법랑질에 접착될 경우 접착실 패가 거의 일어나지 않으며 접착면의 $80 \%$ 이상이 상아질
일 경우에 탈락이 발생함을 보고하였고, Peuman 등 ${ }^{37}$ 은 치경부에서 상아질이 노출될 경우 파절의 가능성이 높아 진다고 하였다. 또한 상아질의 노출 시 많은 문헌에서 즉 시 상아질 봉쇄(immediate dentine sealing)를 시행할 것 을 추천한다. ${ }^{38-40}$

이 외에도 광범위한 레진수복물이 존재하거나 근관치 료 병력이 있는 경우 라미네이트 수복 시 불리할 수 있다. Peuman 등 ${ }^{1}$ 은 87 개의 도재 라미네이트의 10 년간의 경과 관찰(follow-up) 결과 대부분의 변연의 큰 결함(defect)은 기존의 레진수복물이 존재할 경우에 발생하였음을 보고 하였다. 라미네이트 변연에 레진수복물이 존재하는 경우 레진의 중합수축, 낮은 마모저항성, 높은 열팽창계수, 도 재와의 낮은 접착력 등이 부정적인 영향을 미친다.

Magne와 Douglas ${ }^{41}$ 는 인접면 레진수복물이 존재하는 전치에서 라미네이트 수복 시 레진의 중합수축과 온도 변화에 따른 체적변화가 라미네이트 균열발생에 미치는 영향과 인접면연장 정도에 따른 응력발생을 조사하였다. 레진의 중합수축은 도재 라미네이트에 주로 압축력을 발 생시키며 시간에 따라 수분을 흡수하여 응력이 해소되므 로 균열 발생에 치명적인 요인이 되지 못한다. 온도에 따 른 체적변화의 영향과 레진의 중합수축은 서로 상반되어 오히려 라미네이트를 보호하는 효과가 있었다. 인접면연 장 정도는, 레진수복물을 피개하지 않는 경우 변연에서 가장 높은 응력이 발생하였고 인접면을 $100 \%$ 피개하는 경우에 가장 낮은 응력이 발생하였다. 만일 임상적으로 인접면을 $100 \%$ 피개하는 치아형성이 어려운 경우에는 레진 수복물을 50\% 정도 피개하는 'medium wrapping' 의 형태를 추천하였다(Fig. 4).

또한 인접면 레진수복물이 존재하는 경우에 라미네이 트가 레진수복물을 피개 할 수도 있고, 레진수복물을 제 거 후 라미네이트에 포함시킬 수도 있다. Sadighpour 등 ${ }^{42}$ 에 따르면 Class III 레진수복물이 존재하는 경우는 건전 치아와 파절강도, 미세누출면에서 유의한 차이가 없었으 나 기존의 레진 수복물을 제거하고 라미네이트를 수복하 는 경우는 파절강도가 낮아졌다. 또한 이 경우 인접면 와 동에서 시작하는 파절유형을 보였다(Fig. 5).

Gresniqt 등 ${ }^{43}$ 은 기존 레진수복물에 실리카 코팅과 실 란처리를 한 경우 기존 레진수복물에 접착된 라미네이트 가 자연치아에 접착된 라미네이트에 비해 오히려 파절강 도가 높다고 보고하였다. 즉, Class III 레진수복물이 존 재하는 경우 표면 처리 후 $50 \%$ 이상을 피개하는 형태의 라미네이트로 수복할 것을 추천한다. 
A

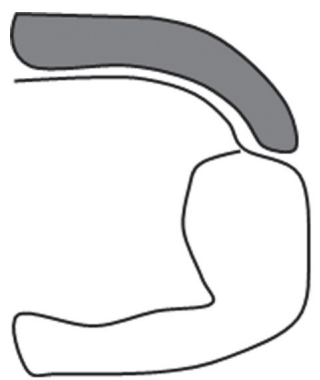

B

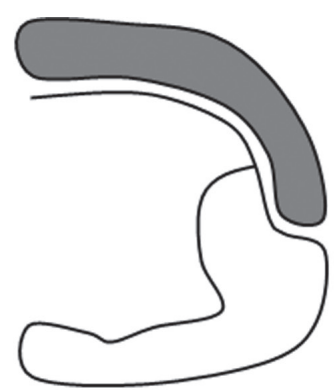

C

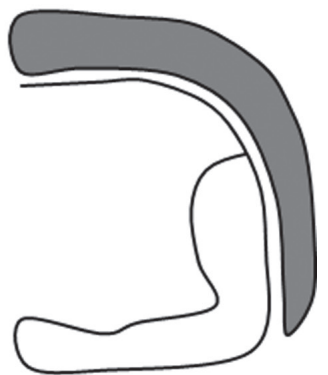

Fig. 4. The margin location of each veneer. ${ }^{41}$ (A) Short wrapping-the veneer was extended only to the facial margin of the preexisting interdental composite. (B) Medium wrapping-the veneer was extended into the bulk of the preexisting composite, penetrating $50 \%$ of the interdental area. (C) Long wrapping-the veneer covered the entire interdental area.
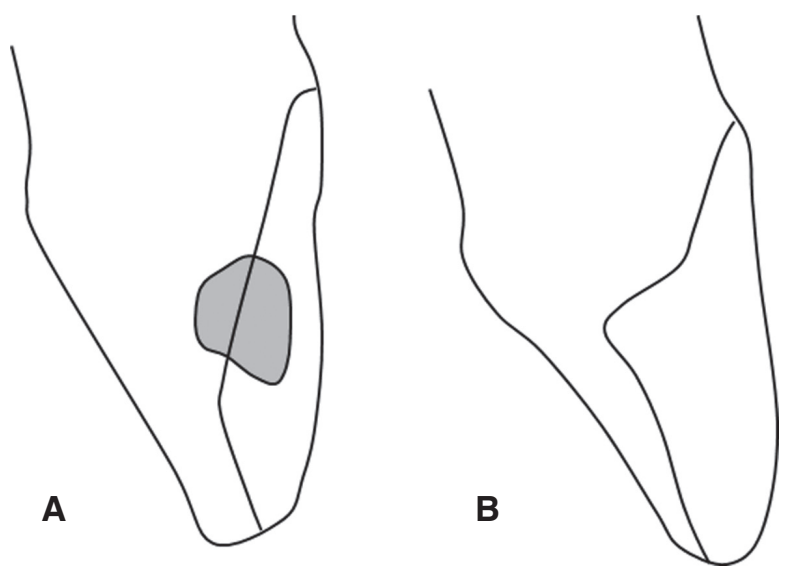

Fig. 5. The design of PLV preparation on tooth with class III composite filling (A), tooth with class IV cavity (B). ${ }^{42}$ PLV, porcelain laminate veneer.

근관치료를 시행한 치아에서 라미네이트로 수복하는 것은 치질보존의 측면에서 장점이 있다. 근관치료 병력 이 라미네이트 수복에 미치는 영향에 관하여는 실패율 이 증가한다는 연구와 ${ }^{44,45}$ 성공률과 큰 상관관계가 없다 는 보고가 함께 존재한다. ${ }^{46} \mathrm{D}^{\prime}$ Arcangelo 등 ${ }^{47}$ 의 연구에 따르면 라미네이트 치아형성과 근관치료는 상악 전치의 파절저항성에는 유의한 영향을 미치지 않으나 치아의 휨 (deflection)을 유의하게 증가시킨다. 이는 법랑질의 두께 가 감소하기 때문이다. 파절은 높은 저작력이 가해질 때 일어나는 드문 일이지만 치아의 휨은 낮은 저작력이 가 해질 때 발생할 수 있으므로 더 중요한 지표이다. 라미네 이트 접착 후에 파절강도는 유의하게 증가하며 치아의 휨은 유의하게 감소하여 건전치아와 비슷해진다. 또한 섬유강화레진 포스트의 수복은 치아의 파절강도를 유의
하게 증가시키는데, 이는 섬유강화레진 포스트가 상아질 의 탄성계수와 유사하며 치질에 결합하기 때문이다. 따 라서 근관치료가 시행된 치아에서 섬유강화레진 포스트 와 라미네이트로 수복하는 것을 치료 옵션 중 하나로 생 각해볼 수 있으나 잔존 치질의 양, 심한 변색 여부 등의 임상적 상황을 주의 깊게 고려하여야 한다. ${ }^{48}$

\section{결론}

여러 문헌을 고찰한 결과 라미네이트 치아형성에 관하 여 다음과 같은 사항들이 추천된다.

전방유도를 재설정 해야 하는 경우 혹은 심미적 요구 로 인해 절단면 길이를 증가시켜야 하는 경우에 절단면 피개를 시행하며 법랑질의 두께가 충분한 경우에는 구개 chamfer형으로, 불충분한 경우에는 butt joint형으로 한다.

$2 \mathrm{~mm}$ 정도 파절 혹은 마모된 치아에서 라미네이트 수 복을 치료 옵션으로 고려할 수 있으며, 변연이 구개오목 에 위치하는 것을 피할 수 있는 치아형성 디자인을 선택 한다.

치경부 변연은 치은연선상에, long chamfer 변연을 형 성한다.

위치 이상, 정중이개, 착색 등의 증례에서 인접면연장 을 시행하며 인접면에 레진수복물 존재 시 표면처리 후 레진수복물의 절반이상을 피개하는 형태의 라미네이트 로 수복한다.

변색이 심하지 않은 근관치료를 시행한 치아에서 라미 네이트 수복 시에는 섬유강화레진 포스트의 사용을 추천 한다. 


\section{ORCID}

Eun-Hye Jo http://orcid.org/0000-0001-8375-2563

Kyung-Ho Ko http://orcid.org/0000-0002-1260-8844

Chan-Jin Park http://orcid.org/0000-0003-4734-214X

Lee-Ra Cho http://orcid.org/0000-0003-3989-2870

Yoon-Hyuk Huh http://orcid.org/0000-0003-4072-5199

\section{References}

1. Peumans M, De Munck J, Fieuws S, Lambrechts P, Vanherle G, Van Meerbeek B. A prospective tenyear clinical trial of porcelain veneers. J Adhes Dent 2004;6:65-76.

2. Burke FJ. Survival rates for porcelain laminate veneers with special reference to the effect of preparation in dentin: a literature review. J Esthet Restor Dent 2012;24:257-65.

3. Radz GM. Minimum thickness anterior porcelain restorations. Dent Clin North Am 2011;55:353-70.

4. Shetty A, Kaiwar A, Shubhashini N, Ashwini P, Naveen D, Adarsha M, Shetty M, Meena N. Survival rates of porcelain laminate restoration based on different incisal preparation designs: an analysis. J Conserv Dent 2011;14:10-5.

5. Sadowsky SJ. An overview of treatment considerations for esthetic restorations: a review of the literature. J Prosthet Dent 2006;96:433-42.

6. Beier US, Kapferer I, Dumfahrt H. Clinical longterm evaluation and failure characteristics of 1,335 all-ceramic restorations. Int J Prosthodont 2012;25: 70-8.

7. Beier US, Kapferer I, Burtscher D, Dumfahrt H. Clinical performance of porcelain laminate veneers for up to 20 years. Int J Prosthodont 2012;25:7985.

8. Smales RJ, Etemadi S. Long term survival of porcelain laminate veneers using two preparation designs: a retrospective study. Int J Prosthodont 2004;17: 323-6.

9. Rucker LM, Richter W, MacEntee M, Richardson A. Porcelain and resin veneers clinically evaluated 2year results. J Am Dent Assoc 1990;121:594-6.

10. Meijering AC, Creugers NH, Roeters FJ, Mulder J.
Survival of three types of veneer restorations in a clinical trial: a 2.5 year interim evaluation. J Dent 1998;26:563-8.

11. Hui KK, Williams B, Davis EH, Holt RD. A comparative assessment of the strengths of porcelain veneers for incisor teeth dependent on their design characteristics. Br Dent J 1991;171:51-5.

12. Highton R, Caputo AA, Mátyás J. A photoelastic study of stress on porcelain laminate preparations. J Prosthet Dent 1987;58:157-61.

13. Magne P, Douglas WH. Design optimization and evolution of bonded ceramics for anterior dentition: a finite-element analysis. Quintessence Int 1999;30:661-72.

14. Zarone F, Apicella D, Sorrentino R, Ferro V, Aversa $\mathrm{R}$, Apicella A. Influence of tooth preparation design on the stress distribution in maxillary central incisors restored by means of alumina porcelain veneers: a 3D-finite element analysis. Dent Mater 2005;21:1178-88.

15. Magne P, Kwon KR, Belser UC, Hodges JS, Douglas WH. Crack propensity of porcelain laminate veneers: a simulated operatory evaluation. J Prosthet Dent 1999;81:327-34.

16. Seymour KG, Cherukara GP, Samarawickrama DY. Stresses within porcelain veneers and the composite lute using different preparation designs. J Prosthodont 2001;10:16-21.

17. Castelnuovo J, Tjan AH, Phillips K, Nicholls JI, Kois JC. Fracture load and mode of failure of ceramic veneers with different preparations. J Prosthet Dent 2000;83:171-80.

18. Hahn P, Gustav M, Hellwig E. An in vitro assessment of the strength of porcelain veneers dependent on tooth preparation. J Oral Rehabil 2000;27: 1024-9.

19. Stappert CF, Ozden U, Gerds T, Strub JR. Longevity and failure load of ceramic veneers with different preparation designs after exposure to masticatory simulation. J Prosthet Dent 2005;94:132-9.

20. Zarone F, Epifania E, Leone G, Sorrentino R, Ferrari M. Dynamometric assessment of the mechanical resistance of porcelain veneers related to tooth preparation: a comparison between two techniques. J Prosthet Dent 2006;95:354-63. 
21. Chaiyabutr Y, Phillips KM, Ma PS, Chitswe K. Comparison of load-fatigue testing of ceramic veneers with two different preparation designs. Int J Prosthodont 2009;22:573-5.

22. Schmidt KK, Chiayabutr Y, Phillips KM, Kois JC. Influence of preparation design and existing condition of tooth structure on load to failure of ceramic laminate veneers. J Prosthet Dent 2011;105:37482.

23. da Costa DC, Coutinho M, de Sousa AS, Ennes JP. A meta-analysis of the most indicated preparation design for porcelain laminate veneers. J Adhes Dent 2013;15:215-20.

24. Shetty A, Kaiwar A, Shubhashini N, Ashwini P, Naveen D, Adarsha M, Shetty M, Meena N. Survival rates of porcelain laminate restoration based on different incisal preparation designs: an analysis. J Conserv Dent 2011;14:10-5.

25. Wall JG, Reisbick MH, Johnston WM. Incisal-edge strength of porcelain laminate veneers restoring mandibular incisors. Int J Prosthodont 1992;5:4416.

26. Ako lu B, Gemalmaz D. Fracture resistance of ceramic veneers with different preparation designs. J Prosthodont 2011;20:380-4.

27. Rouse JS. Full veneer versus traditional veneer preparation: a discussion of interproximal extension. J Prosthet Dent 1997;78:545-9.

28. Rosenthal L. Diastema closure utilizing porcelain veneers - simple and advanced. Dent Econ 1994;84:63-4.

29. Knight LD. Use of porcelain for treating a maxillary central diastema. Gen Dent 1992;40:498-9.

30. Chun YH, Raffelt C, Pfeiffer H, Bizhang M, Saul G, Blunck U, Roulet JF. Restoring strength of incisors with veneers and full ceramic crowns. J Adhes Dent 2010;12:45-54.

31. Guess PC, Stappert CF. Midterm results of a 5-year prospective clinical investigation of extended ceramic veneers. Dent Mater 2008;24:804-13.

32. Troedson M, Dérand T. Effect of margin design, cement polymerization, and angle of loading on stress in porcelain veneers. J Prosthet Dent 1999; 82:518-24.

33. Pahlevan A, Mirzaee M, Yassine E, Ranjbar Omra- ny L, Hasani Tabatabaee M, Kermanshah H, Arami S, Abbasi M. Enamel thickness after preparation of tooth for porcelain laminate. J Dent (Tehran) 2014; 11:428-32.

34. Rosenstiel SF, Land MF, Fujimoto J. Contemporary fixed prosthodontics. 4th ed. New York; Mosby; 2006. p. 330-1.

35. Burke FJ. Survival rates for porcelain laminate veneers with special reference to the effect of preparation in dentin: a literature review. J Esthet Restor Dent 2012;24:257-65.

36. Friedman MJ. A 15-year review of porcelain veneer failure - a clinician's observations. Compend Contin Educ Dent 1998;19:625-8.

37. Peumans M, De Munck J, Fieuws S, Lambrechts P, Vanherle G, Van Meerbeek B. A prospective tenyear clinical trial of porcelain veneers. J Adhes Dent 2004;6:65-76.

38. Magne P, Douglas WH. Porcelain veneers: dentin bonding optimization and biomimetic recovery of the crown. Int J Prosthodont 1999;12:111-21.

39. Magne P, Kim TH, Cascione D, Donovan TE. Immediate dentin sealing improves bond strength of indirect restorations. J Prosthet Dent 2005;94:5119.

40. Magne P, So WS, Cascione D. Immediate dentin sealing supports delayed restoration placement. J Prosthet Dent 2007;98:166-74.

41. Magne P, Douglas WH. Interdental design of porcelain veneers in the presence of composite fillings: finite element analysis of composite shrinkage and thermal stresses. Int J Prosthodont 2000;13:117-24.

42. Sadighpour L, Geramipanah F, Allahyari S, Fallahi Sichani B, Kharazi Fard MJ. In vitro evaluation of the fracture resistance and microleakage of porcelain laminate veneers bonded to teeth with composite fillings after cyclic loading. J Adv Prosthodont 2014;6:278-84.

43. Gresnigt MM, Ozcan M, Kalk W, Galhano G. Effect of static and cyclic loading on ceramic laminate veneers adhered to teeth with and without aged composite restorations. J Adhes Dent 2011;13:56977.

44. Meijering AC, Creugers NH, Roeters FJ, Mulder J. Survival of three types of veneer restorations in a 
clinical trial: a 2.5-year interim evaluation. J Dent 1998;26:563-8.

45. Shaini FU, Shortall AC, Marquis PM. Clinical performance of porcelain laminate veneers. A retrospective evaluation over a period of 6.5 years. J Oral Rehabil 1997;24:553-9.

46. Magne P, Douglas WH. Cumulative effects of successive restorative procedures on anterior crown flexure: intact versus veneered incisors. Quintessence Int 2000;31:5-18.
47. D'Arcangelo C, De Angelis F, Vadini M, Zazzeroni S, Ciampoli C, D'Amario M. In vitro fracture resistance and deflection of pulpless teeth restored with fiber posts and prepared for veneers. J Endod 2008;34:838-41.

48. D'Arcangelo C, De Angelis F, Vadini M, D'Amario M, Caputi S. Fracture resistance and deflection of pulpless anterior teeth restored with composite or porcelain veneers. J Endod 2010;36:153-6. 


\section{라미네이트 치아형성 디자인에 관한 문헌고찰}

\section{조은혜, 고경호, 박찬진, 조리라, 허윤혁*}

강릉원주대학교 치과대학 치과보철학교실 및 구강과학연구소

성공적인 라미네이트 치료를 위해서는 치아형성 방법이 매우 중요하다. 법랑질에 국한된 보존적인 치아형성, 치태조절이 용이한 치은연선상(equigingival) 변연, 가능한 존재하는 접촉점의 유지 등의 조건이 일반적으로 알려져 있으나 구체적인 치아형성 디자인에 관하여는 논쟁의 여지가 존재한다. 생역학적으로 고려해볼 때, 다음과 같은 사항들이 추천된다. 절단 면 피개는 심미적 요구와 전방유도의 재설정 필요 여부 측면에서 결정해야 하며, 법랑질 두께가 충분한 경우에는 구개측 연장을 하는 것이 좋으나 응력 집중이 큰 구개오목(palatal concavity)에 변연이 위치하는 것은 부적절하다. 인접면 연장은 증례에 따라 선택적으로 시행하며, 인접면에 레진수복물이 존재하는 경우에는 표면처리 후 레진 수복물을 절반 이상 피 개하는 형태의 라미네이트로 수복한다. 변색이 심하지 않은 근관치료가 시행된 치아의 경우 라미네이트 수복을 고려해 볼 수 있으며, 이 때 섬유강화레진 포스트를 사용하는 것을 추천한다.

(구강회복응용과학지 2016;32(3):149-57)

주요어: 라미네이트; 치아형성; 법랑질; 구개오목; 인접면

*교신저자: 허윤혁

(25457) 강원도 강릉시 죽헌길 7 강릉원주대학교 치과대학 치과보철학교실

Tel: 033-640-2761 || Fax: 033-640-3103 | E-mail: vino@gwnu. ac. kr

접수일: 2016년 9월 1일 | 수정일: 2016년 9월 9일 | 채택일: 2016년 9월 12일 